\title{
NO SÓLO UNA FLOR: APROXIMACIÓN A LA PRESENCIA DE LA PEONÍA EN LA MEDICINA Y EL ARTE
}

\author{
Araceli Moreno Coll
}

\begin{abstract}
Resumen: El presente artículo pretende dar otra visión al mundo vegetal. Analizaremos el papel de la peonía en distintas culturas, dándonos cuenta de que no es un simple attrezzo usado por la belleza de sus flores, pues esconde innumerables incógnitas.
\end{abstract}

Palabras clave: Peonía, flores, Virgen del Rosal, pintura religiosa, retablo, símbolo, Abundancia, alegoría, horimono, óleo, papel, tinta.

Not just a flower: an approach to the presence of peony in Medicine and Art

Abstract: The present article attempts to give another perspective to the vegetable world. We will analyze the role of peonies in different cultures, realizing that it is not just an atrezzo used because of the beauty of its flowers, as it hides countless mysteries.

Key words: Peony, flowers, Madonna of the Rose, religious painting, altarpiece, symbol, Abundance, allegory, horimono, oil, paper, ink.

\section{INTRODUCCIÓN}

¿Es la peonía sólo una flor? A través de esta premisa, pretendemos desarrollar nuestro discurso, pues aunque en la actualidad es ampliamente valorada por su belleza en el ámbito de la decoración floral -sobre todo en ramos nupciales donde se ha puesto de modafue sin embargo, una planta muy difundida en Europa en estado silvestre, gozando desde la Antigüedad hasta el siglo XVIII de alta estima en su empleo con fines medicinales.

Plinio el Viejo (23-79), Dioscórides (c. 40-c. 90) o Galeno de Pérgamo (130-c. 200/216) fueron algunos de los autores que se ocuparon de sus propiedades mágico-médicas, recogidas posteriormente en textos latinos tardoantiguos y medievales que dieron continuidad a esta tradición (Ferraces, 2009). Pese a ello, es sintomático el desconocimiento general de las propiedades terapéuticas y simbólicas de la peonía.

Con este trabajo pretendemos otorgarle la relevancia que hoy en día parece olvidada así como intentar demostrar que esta planta utilizada como recurso artístico no es un mero elemento vegetal ornamental dispuesto por el artista sobre la superficie de su obra. La peonía puede desempeñar un efecto apotropaico así como adquirir distintos significados dependiendo del ámbito geográfico donde se encuentre representada, ayudando con ello a su artífice a conformar un mensaje.

Data de recepció: 29 d'octubre de 2016 / Data d'acceptació: 20 de desembre de 2016. 
Lo que planteamos por tanto, es una aproximación al simbolismo de esta flor a lo largo de la historia a través de distintas manifestaciones artísticas. No obstante, hay que decir que este trabajo debe ser considerado una pequeña muestra a través de la selección de distintos ejemplos, pudiendo ser el inicio de futuras investigaciones.

El discurso se organiza en varios apartados. Comenzaremos hablando brevemente de la etimología de la palabra peonía, seguiremos con las características botánicas de la planta, y a continuación procederemos al estudio de su representación. Las primeras obras que analizaremos son ilustraciones que forman parte de un tratado de fitoterapia y uno de botánica. A través de ellas, se mostrará la relevancia que adquirió la peonía en el campo de la medicina, ya que sus raíces y semillas fueron usadas durante largo tiempo como remedio para aliviar determinadas dolencias. Proseguiremos con el estudio de esta flor en una obra religiosa, en la que descubriremos que junto a otros símbolos marianos ayuda a transmitir un discurso a los fieles. Seguidamente, profundizaremos en una pintura alegórica, donde su imagen se encuentra pintada entre un inmenso horror vacui de especímenes creados por la madre naturaleza. Para concluir abordaremos la representación de la peonía en la cultura asiática, ampliamente representada y valorada, símbolo de tradiciones y buenos augurios.

Entre las dificultades encontradas para realizar el presente trabajo se encuentra la bibliografía. El estudio del simbolismo de la peonía ha sido objeto de escasas investigaciones, quizá porque es una flor menos utilizada como recurso vegetal que la azucena ${ }^{1}$ y la rosa $^{2}$, o debido a que ha podido ser confundida con esta última si no se ha efectuado con detallismo y precisión ${ }^{3}$. Por ello, en este artículo se ha recurrido como fuente a diversas obras sobre simbología que nos ayudarán a entender el significado de esta flor a lo largo del tiempo y su plasmación en distintos soportes (Becker, 2003; Bruce-Mitford, 2000; Chevalier, 1991; Dafne \& Cloe, 2014; Eberhard, 1998; Levi d'Ancona 1977; Rey 2008).

\section{ETIMOLOGÍA}

El nombre de peonía (paiônía) procede de Peán (Paiôn), apelativo que puede traducirse como socorredor (Quer, 1784, 43). Fue citada por Plinio el Viejo como la planta medicinal más antigua (Levi D’Ancona, 1977, 300). En los poemas homéricos figura un dios "sanador" denominado Peón o Peán que trató a Hades sirviéndose de plantas al ser herido por Heracles". En la Ilíada se lee: "Peón espolvoreó encima medicinas, aletargadoras del

${ }^{1}$ Esta flor se encuentra en la mayoría de anunciaciones, tal es el caso de la Anunciación, en Las Muy Ricas Horas del Duque de Berry, f. 26r o la pintada por Jacomart a mediados del siglo XV que se encuentra en el Museo de Bellas Artes de Valencia.

${ }^{2}$ La rosa es un recurso ampliamente utilizado por los artistas, tanto para ser incluida en obras de temática religiosa como símbolo mariano, como atributo de alguna mártir (Santa Dorotea) o simplemente para crear junto a otras flores un bodegón o guirnalda.

${ }^{3}$ Son muchos los tratados de fitoterapia realizados en el Medievo que no otorgaron importancia a la representación natural de las plantas, haciéndolas prácticamente inidentificables a no ser por la cartela con su nombre en el texto. Muestra de ello es el manuscrito Kräuterbuch escrito en 1462 por Johannes Hartlieb (c. 1410-1468) -médico personal del duque Alberto III de Baviera-e ilustrado con dibujos de ciento sesenta especies de gran imprecisión botánica. Si las flores no se representan fidedignamente puede generar cierta confusión en su estudio.

${ }^{4}$ Hay autores que se refieren a la misma información utilizando nombres romanos (Quer, 1784, 43; Cullen, 1795, 524). Aunque Homero establece en la Ilíada y Odisea que fue el phsico Peonios quién curó 
dolor, y lo curó; pues en absoluto tenía una hechura mortal" (canto V, 401). También sanó a Ares de sus heridas bajo los muros de Troya (Ilíada, canto V, 899-900). Por otro lado, la Odisea hace referencia a la estirpe de Peán:

La nacida de Zeus guardaba estos sabios remedios: se los dio Polidamna, la esposa de Ton el de Egipto, el país donde el suelo fecundo produce más drogas cuyas mezclas sin fin son mortales las unas, las otras saludables; mas todos los hombres alli son expertos como nadie en curar, porque traen de Peán su linaje (canto IV, 232).

Peón fue un personaje mítico griego considerado médico de dioses, hijo de Endimión y hermano de Epeo, del que usurpó los derechos de descendencia reinando sobre la Caria. Más tarde se retiró a un país que de él tomó el nombre de Peonía (Sechi, 2007, 213-214). Con el tiempo, este individuo fue asimilado por Apolo ${ }^{5}$ y suplantado por Asclepio (Grimal, 1981, 413). Debemos tener presente que en este periodo, los conceptos enfermedad y remedio se vinculan a aspectos trascendentes de las creencias religiosas (Cabello, 2010, 75).

\section{CARACTERÍSTICAS BOTÁNICAS}

La peonía constituyó durante tiempo parte de las ranunculáceas (Ranunculaceae). No obstante, su clasificación se ha modificado, pasando a constituir su propia familia: peoniáceas (Paeoniaceae) (González, 1980, 973) ${ }^{6}$. El único género, Paeonia, presenta más de treinta especies aceptadas incluidas en tres grupos: montaña, al que pertenecen las peonías arbóreas, nativas de China y Tíbet; onaepia que contiene dos especies oriundas de la Costa Oeste; y paeon, formado por especies herbáceas nativas de Europa, Asia y África. Dentro del último grupo, la más común es la Paeonia lactiflora denominada Peonía china, Paeonia híbrida, rosa de monte o rosa sin espinas. Entre las arbustivas, destaca la Paeonia suffructicosa, que ha dado origen a nuevos especímenes. En general, presentan raíces gruesas, carnosas y fasciculadas, tallo alto con hojas alternas y subdivididas en lacinias más o menos largas. El fruto es una vaina que encierra semillas rojas. Florecen entre abril y junio, tienen cinco sépalos y entre cinco o diez pétalos de distintos colores según especie. Las flores varían su forma -dependiendo del proceso de apertura, edad de la planta y suelo donde se establecen- pudiéndose clasificar en: simple, doble (tipo rosa), semidoble, japonesa, anémona, corona, bomba y semi-rosa. Poseen un amplio abanico de colores: blancas, blancas sonrosadas, amarillas, carne, rosa-plateado, rosa de flor de manzano, rosa cereza, rosa puro, carmesí brillante, rojo intenso, carmesí negro e incluso con centros de distinto color.

al dios Pluto cuando fue herido por Hércules, no se nombra específicamente como Peonías (Levi D’Ancona, 1977, 300).

${ }_{5}^{5}$ Giuseppina Sechi le otorga el nombre de Peonio y en cuyo honor se cantaba el himno de Peán (Sechi, 2007, 214).

${ }^{6}$ Para mayor información al respecto ver: Osborne, 2007. 


\section{LA PEONÍA EN TRATADOS (Fitoterapia) Y BOTÁNICA}

Como apunta Arsenio Ferraces (2009, 149), la especie botánica de la peonía fue apreciada desde la Antigüedad, y es aludida reiteradamente por su empleo en prácticas mágicas, ya sea con fines curativos, para la confección de filtros o amuletos con función preventiva. Los primeros ejemplos donde aparece la planta son tratados botánicos como $D e$ Historia plantarum de Teofrasto (371-287 a. C. $)^{7}$, considerado el origen de las floras -entendido como el conjunto de plantas de un país o región- desde el punto de vista científico. En su trabajo revela el método de recolección:

Dicen que la peonía, que algunos llaman glykysíde, hay que arrancarla de noche, porque, si alguien lo hace por el día y es observado por un pico carpintero cuando está cogiendo el fruto, corre el riesgo de perder la visión, y si lo ve cuando está cortando la raíz, puede contraer flojedad de vientre (Teofrasto, 1988, 461).

Galeno de Pérgamo (130-c. 200/216) y Plinio el Viejo, se ocuparon también de sus aplicaciones mágico-médicas, y numerosos textos latinos tardoantiguos y medievales dieron continuidad a esta tradición. Se escribieron con fines curativos detallando diversos remedios obtenidos a partir de vegetales y, en ocasiones, de animales y minerales. Es recurrente en dichas obras el nombre de la planta, sinónimo, descripción de sus características, distribución geográfica, hábitat, enumeración de los primeros autores que la citaron y sus propiedades terapéuticas.

La primera ilustración (Fig. 1) pertenece al códice Dioscurides Neapolitanus que contiene la obra de Pedacio Dioscórides, un tratado en cinco libros titulado Perì üles iatrichès conocido en latín como De materia medica. El manuscrito en sus ciento setenta páginas alude a las plantas medicinales conocidas hasta ese momento.

Dioscórides fue un médico y botánico griego nacido en Anazarbeo cerca de Tarso, en Cilicia (actual Turquía), que escribió lo que se considera el manual más significativo de medicina y farmacopea de Grecia y Roma. La obra engloba la eficacia terapéutica de las sustancias naturales. Se tradujo al árabe en el siglo X, en época de Abderramán III (891961) y en 1518, Antonio de Nebrija (1444-1522) realizó la primera traducción al latín. Posteriormente, Andrés de Laguna (1499-1559) -médico del Papa Julio III- hizo una versión en castellano a la que añadió sus dibujos (Laguna, 1555). Los ejemplares De materia medica se ilustraron en la Antigüedad con pinturas de plantas del natural, copiadas posteriormente sin conocer las especies que se representaban, dando lugar a imágenes esquemáticas o deformadas, suponiendo un problema para su identificación (López Piñero, 1996, 11).

La peonía figura en antiguos recetarios por las propiedades de sus raíces y semillas. Dioscórides (c. 500-699, 102) distingue en su obra las de la hembra (Paeonia foemina) que corresponde a Paeonia officinalis Retzius y las del macho (Paeonia masculum) identi-

\footnotetext{
${ }^{7}$ La obra fue escrita en el siglo IV a.C., pero para el presente trabajo se ha utilizado la versión: Teofrasto (1988): Historia de las plantas [Introducción, traducción y notas por José María Díaz-Regañón López], Madrid, Gredos.
} 
Fig. 1. Dioscórides, P. (c. 500-699), Dioscurides Neapolitanus, Biblioteca Nacional de Nápoles.

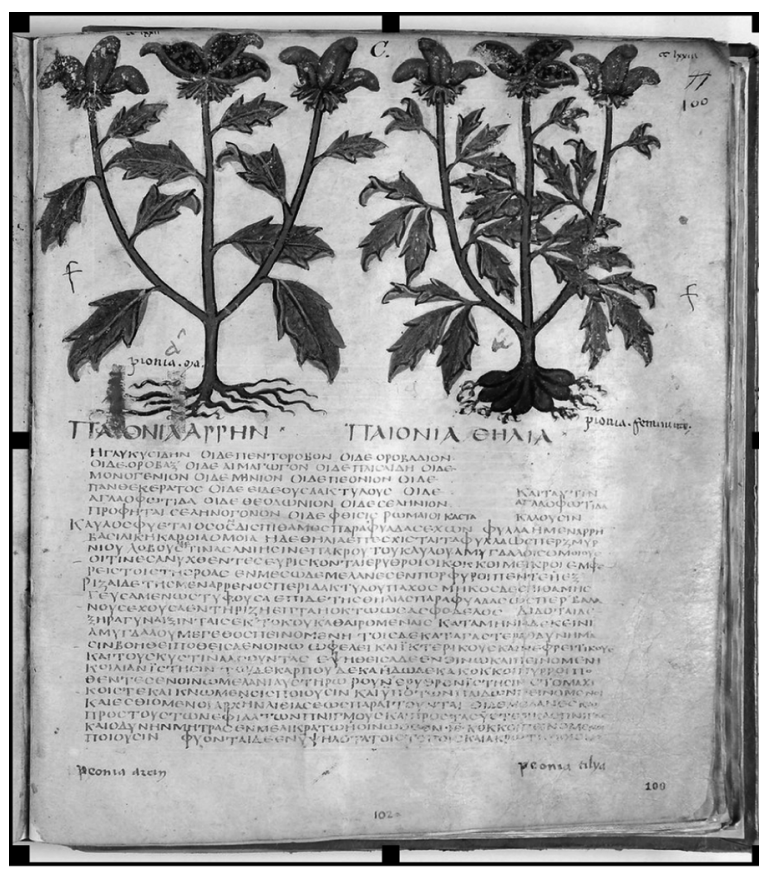

ficada como Paeonia mascula ${ }^{8}$. En la traducción de Laguna $(1555,364)$ respecto a la fémina se lee:

Dase á bever en polue à las mugeres que no quedaron bien purgadas del parto: porque provoca el menstruo, be vida en quantidad de una almendra. Si se beve con vino, es util á los dolores de tripas, sirue cóntra el mal de ictetitia, y contra el dolor de vexiga, y riñones. Cocida en vino, y beuida, restriñe el vientre. Bevidos X ó XI de sus granos roxos, con vino negro, y austero, detienen el menstruo roxo. $Y$ comidos mitigan las mordicationes de estomago. Dados á comer, ó á bever, á los niños quando se les comiença á engendrar la piedra, se la resuelven. Los granos negros tienen virtud contra la suffocation que causa la madre, y contra los dolores que la atormenta, beviendose XV dellos con aguamiel, ó con vino.

En el Dioscurides Napolitanus las plantas no se representan fidedignamente, pues lo que interesa resaltar son las partes de éstas que poseen propiedades curativas. Por ello el autor destaca en la peonía sólo sus semillas rojas y negras además de sus raíces. Serán muchos los autores a lo largo del tiempo que se harán eco de sus peculiaridades. El médico y botánico español Joseph Quer $(1784,42-43)$ distingue -como ya hizo Dioscórides- la peonía femenina y masculina, y se refiere a que “(...) se usan ordinariamente las raices, semillas, y algunas veces las flores contra las convulsiones, epilepsia, paralysis, vapores y otras enfermedades, que dependen de la irritacion del genero nervioso". Por otro lado,

${ }^{8}$ En la traducción de Andrés Laguna no figura la imagen de la Paeonia mascula. 


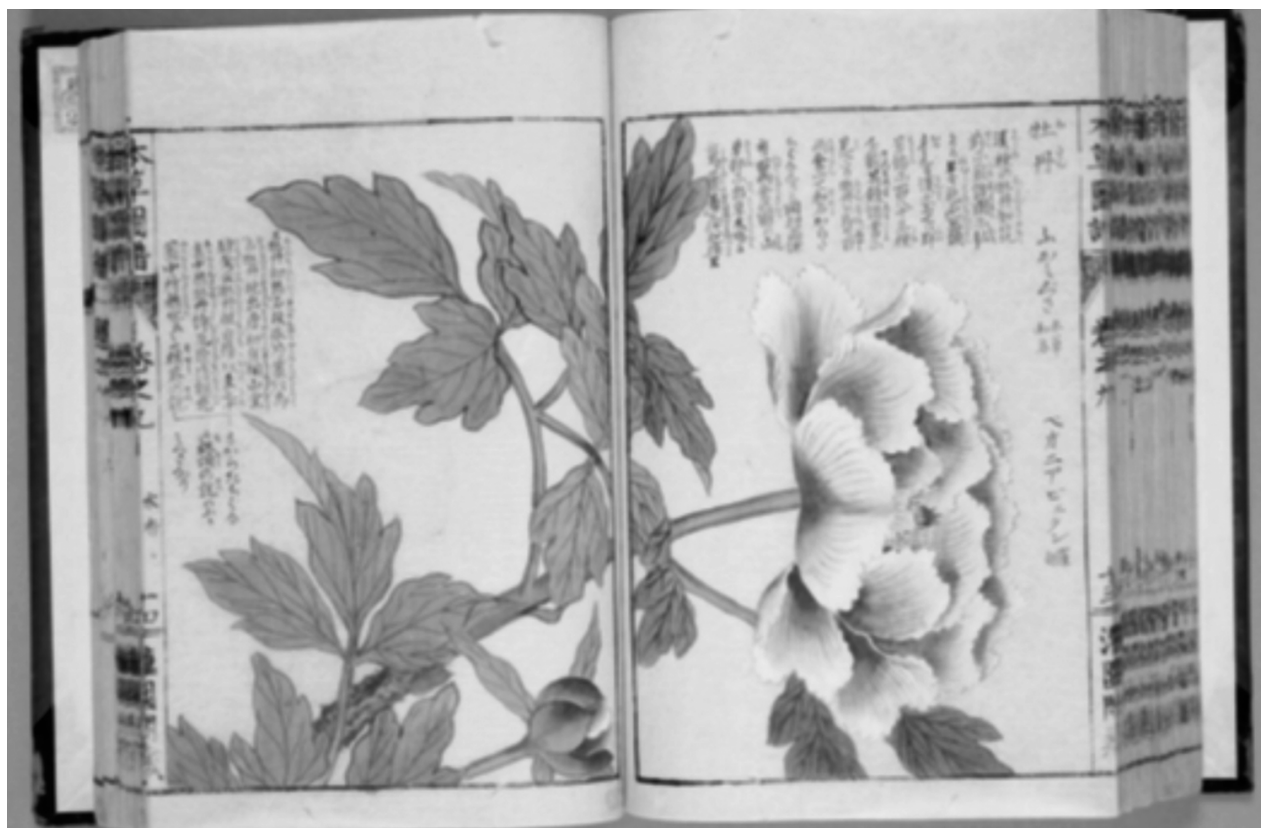

Fig. 2. Iwasaki Kan'en (c. 1830-1844), Manual ilustrado de plantas medicinales, Biblioteca Digital Mundial.

según William Cullen (1795, 524-525) "desde el tiempo de Galeno han variado el uso y reputación de esta planta; algunos médicos la han encargado por sus virtudes; y otros se han quejado de haberla dado inútilmente (...)". Pero no sólo existen este tipo de tratados en el mundo occidental, muestra de ello es el Manual ilustrado de plantas medicinales, escrito por el vasallo del shogunato Iwasaki Kan’en (1786-1842) y publicado en Japón a finales del periodo Edo (Fig. 2) ${ }^{9}$.

El interés por el saber botánico se experimentó en Europa a comienzos del siglo XVI. Como apunta María José López Terrada (2009, 454-460), las expediciones científicas dieron a conocer nuevas especies vegetales de Asia, África y América favoreciendo su difusión. La fitología, nació de la necesidad del ser humano por entender el mundo vegetal, aprovechar sus valores alimenticios y profundizar en la técnica de selección, aclimatación, hibridación y clasificación. Se empezaron a escribir entonces numerosos libros acerca de esta disciplina, todos ellos magníficamente ilustrados como sucede en el Hortus Eystettensis de Basilius Besler. Estas estampas se convirtieron en un magnífico instrumento de apoyo para los conocimientos científico de tipo descriptivo.

Besler (1561-1629), nacido en Núremberg, fue médico, farmacéutico, botánico y curador del jardín botánico del obispo Johann Konrad von Gemmingen, quien le encomendó

${ }^{9}$ Formado por noventa y dos volúmenes donde se incluyen más de mil novecientas variedades vegetales en ilustraciones a color y explicaciones biológicas. Las plantas se clasifican y organizan según el Honzō kōmoku, libro chino de medicina de la dinastía Ming del siglo XVI. 
Fig. 3. Besler (1613), Hortus Eystettensis, Biblioteca Digital Jardín BotánicoCSIC.

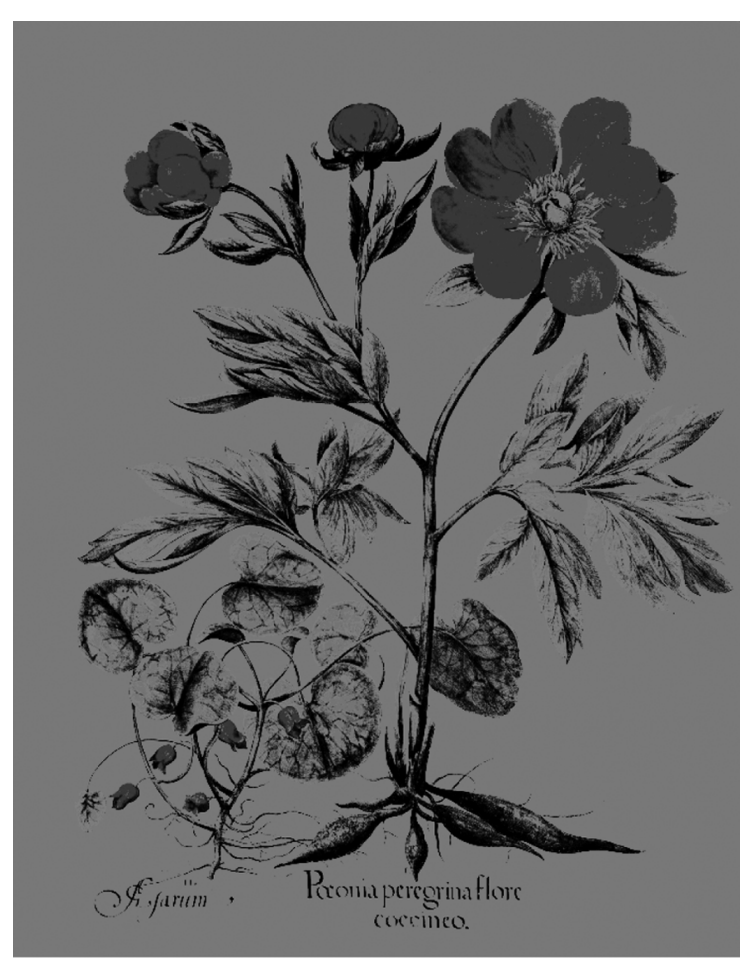

la elaboración de un códice con las plantas que allí crecían. Contó para ello con la ayuda de su hermano así como de un equipo de dibujantes y grabadores germanos. El libro se publicó en 1613 con trescientas sesenta y siete ilustraciones, obra que se volvió a editar en Núremberg en 1640 y 1713. En él se distinguen varias imágenes de paeonia, algunas dibujadas con raíz, otras cortadas por el tallo, peonías junto a otras plantas, flores abiertas, capullos o destacando sus simientes (Fig. 3). A través de este tipo de obras comprobamos que el interés de la ciencia llega al mundo vegetal donde cada vez se irán incorporando nuevas especies.

\section{PEONÍAS EN LA PINTURA RELIGIOSA: La Virgen del jardín de las rosas}

Martin Schongauer (1450-1491) es el autor de la acuarela Estudios de peonía (Fig. 4) que se encuentra en el J. Paul Getty Museum de Los Ángeles y que usó como base de las peonías situadas en su obra La Virgen del jardín de las rosas (1473) de la iglesia de San Martín de Colmar en Francia (Turner y Hendrix, 1997, 54). La pintura también es conocida como La Virgen del rosal o La Virgen y el niño en el jardín de las rosas y sustituye a una similar y de mayor tamaño (c. 250 x $165 \mathrm{~cm}$.) cuya copia realizada por su taller está en el Museo Isabella Stewart Gardner en Boston (Fig. 5). 


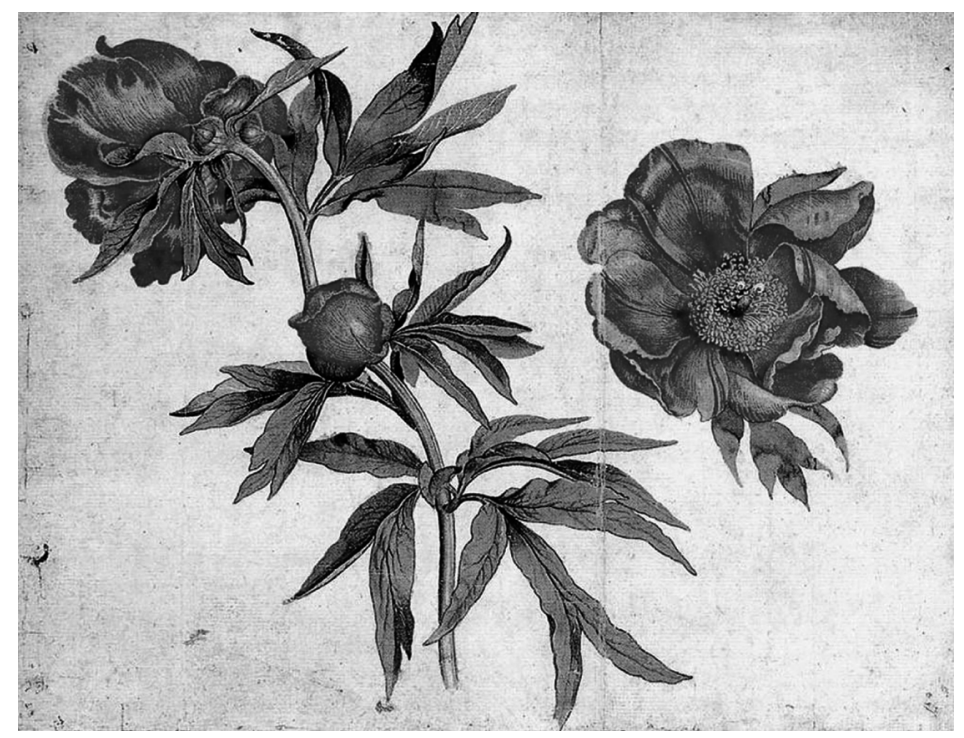

Fig. 4. Martin Schongauer, Estudios de peonías, J. Paul Getty Museum, Malibú (California).

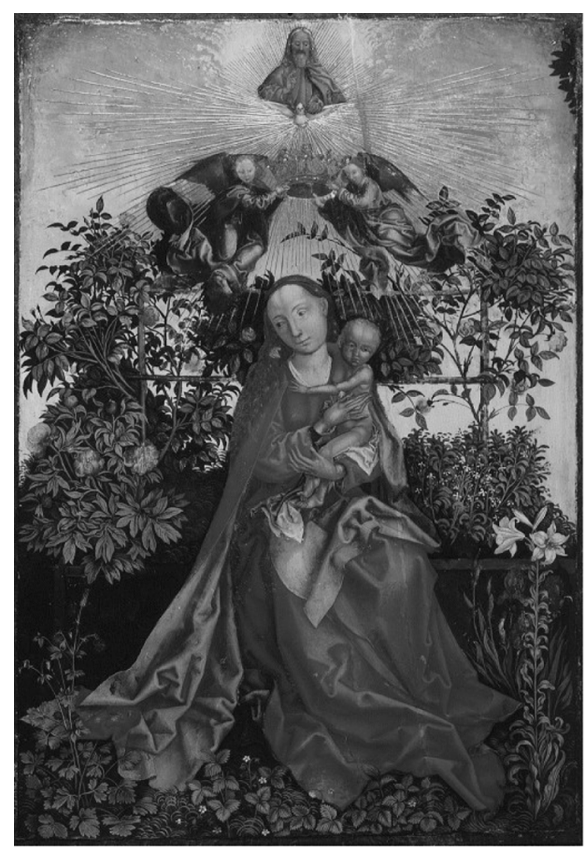

Fig. 5. Martin Schongauer (taller), La Virgen y el niño en el jardín de las rosas, Museo Isabella Stewart Gardner, Boston (EE.UU.). 
Fig. 6. Martin Schongauer, Virgen del rosal, 1473. Iglesia de los dominicos de Colmar (Francia).

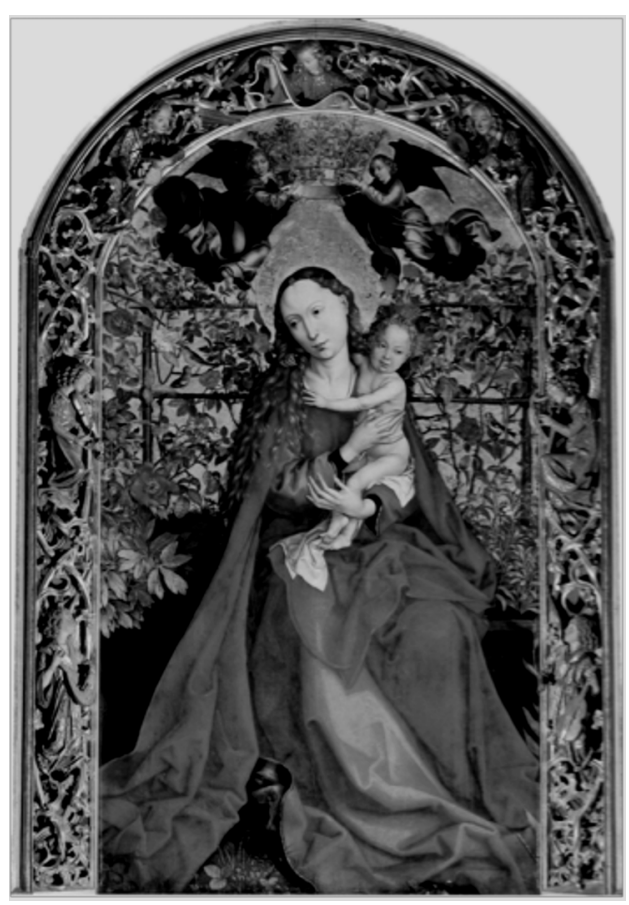

En la obra de Colmar, se presenta en el centro compositivo a la Virgen sentada sosteniendo entre sus brazos al niño Jesús, siendo ésta coronada por dos ángeles (Fig. 6). La escena se desarrolla en el hortus conclusus, interpretación del pasaje del Cantar de los Cantares en el que se lee: "Eres jardín cercado, hermana mía, esposa; eres jardín cercado, fuente sellada" (Cant 4, 12). Este espacio dentro del cristianismo fue exégesis de la virginidad y de la Inmaculada Concepción de María (Beck, 2000, 388; Úzquiza, 2012, 142). Entre la vegetación sobresalen: rosas, fresas, lirios, alhelíes, destacando en el lado derecho de la Virgen tres peonías así como distintas especies de pájaros (jilguero, petirrojo y pinzón) ${ }^{10}$. Cada elemento de la obra tiene significación propia por sí mismo, sin embargo, aquí todos al unísono hacen referencia a la Encarnación -momento en que Jesús es concebido milagrosamente por la Virgen María- y Pasión -episodios que narran los sucesos de Jesucristo, entre ellos su crucifixión, muerte y resurrección- como detallaremos a continuación.

Comencemos por la indumentaria que luce la Virgen. Ésta viste túnica y manto de color carmesí convirtiéndose en el cáliz que contiene la sangre transubstanciada del Salvador. El rojo de la sangre establece además la conexión con el vino, elemento eucarístico de la vida

${ }^{10}$ Muchos de estos elementos se representan en la obra Jardín del Paraíso, c. 1410-1420). Städelsches Kunstinstitut und Städtische Galerie. Fráncfort del Meno, Alemania. Anónimo activo en el Alto Rin a principios del siglo XV. Es uno de los primeros ejemplos donde las plantas se pintan de manera realista facilitando su identificación. 
espiritual presente durante la liturgia cristiana (Bynum, 1988, 81; Revilla, 2012, 647). El artista sitúa tras María un enrejado con rosas de dos colores: blancas (Rosa x alba L.) símbolo de su pureza, y rojas (Rosa gallica L.) que aluden al sufrimiento, al amor y a las llagas de Cristo ${ }^{11}$ (Chevalier, 1991, 892). Según Carmen Añón (1996, 26), una leyenda narra que la rosa antes de crecer con las demás flores en la Tierra, había nacido en el cielo sin espinas dado que no temía mal alguno. Sin embargo, éstas le salieron después de la caída del hombre, para recordar con su belleza y fragancia, el esplendor del Paraíso y, con sus espinas el pecado mortal. En relación a esta tradición se dice que la Virgen es como una "rosa sin espinas", ya que está exenta del pecado original. El Niño desnudo se asienta sobre el paño de pureza que sirvió para ocultar la desnudez de Jesús de Nazaret durante su crucifixión.

Las fresas (Fragaria) se refieren al Paraíso, cuyo origen se remonta a la interpretación del pasaje "Las edades del hombre" de las Metamorfosis de Ovidio (libro I, 104), donde se dice que durante la Edad de Oro ${ }^{12}$ el hombre se alimentaba de frutos ofrecidos de la tierra, entre ellos fresas. Sus hojas tripartitas aluden a la Trinidad ${ }^{13}$, las pequeñas flores blancas se interpretan como la inocencia y humildad de la Virgen, y su color rojo remite a la sangre derramada en la futura Pasión de Cristo (Beck, 2000, 387; Del Olmo, 2008, 12; Úzquiza, 2012, 125).

Vemos la presencia del alhelí (Matthiola incana L.), de la familia de las crucíferas que con sus cuatro pétalos forman una cruz natural señalando el modo en que morirá Jesús (Gómez Moreno, 2011, 174). Los encontramos de dos colores; blancos -aludiendo de nuevo a la pureza virginal de María- y rojos, color de la sangre.

El artista sitúa a la izquierda de la Virgen un lirio cárdeno (Iris germánica L.). En ocasiones se usa en lugar de la azucena, sobre todo en la pintura de los Países Bajos (Úzquiza, 2012, 151). Su color azul es símbolo de virginidad y castidad -haciendo mención a la Encarnación- pero también de revelación, fe, fidelidad, verdad y la eternidad de Dios (Balderas, 2008, 527). También puede aludir a la estirpe de David a la que pertenecía María (Escobar y Díaz, 1993, 22). Sus hojas en forma de espada, remiten al dolor de ésta ante la muerte de su hijo, interpretación del pasaje evangélico en el que Simeón le dice: “ $y$ una espada atravesará tu alma" (Lc, 2, 35), palabras premonitorias del futuro sufrimiento del Mesías. En el lado opuesto, las hojas de aguileña (Aquilegia vulgaris L.) figuran por su forma trilobulada el dogma en el que Dios es un ser único que existe como tres personas distintas: Padre, Hijo y Espíritu Santo (Becker, 2003, 21). Esta flor fue incorporada durante el Renacimiento entre los símbolos de la Pasión de Cristo (Úzquiza, 2012, 7).

Detrás del Niño, se sitúan tres jilgueros europeos o cardelinas (Carduelis carduelis), uno joven y dos adultos identificables por su máscara facial carmesí. La unión de estos elementos simbolizan la conexión entre Encarnación y Pasión, y recuerda el último capítulo de la vida de Cristo: crucifixión y resurrección. Se relacionan por otra parte con su-

11 “(...) veisle aqui inmortal, glorioso, impasible, triunfador de la muerte y del infierno: veisle aquí rubricado con cinco hermosísimas rosas, las llagas quiero decir con que hermosea y adorna su sacratísimo cuerpo (...)". Texto extraído de: Manual de piadosas meditaciones, 1833, 141.

12 Esta primera etapa de "Las edades del hombre" aconteció inmediatamente después de la Creación donde la humanidad era todavía pura.

${ }^{13}$ En la copia realizada por el taller de Shongauer aparece representada la figura Dios Padre en el cielo además de la paloma (referida al Espíritu Santo) y Dios hijo, por tanto se ve mejor el significado de las fresas y la aguileña alusivas a la Trinidad. 
persticiones del medievo, ya que se creía que tenía poderes curativos, convirtiéndose en símbolo de esperanza. El jilguero hace referencia al sufrimiento de Jesús por su nombre latino carduelis que subraya el hecho de que se alimenta de cardos. Según la tradición auxilió a éste quitándole las espinas de la frente, de ahí su mancha roja distintiva (BruceMitford, 2000, 70; Del Olmo, 2008, 7; Úzquiza, 2012, 156).

Al lado de la Virgen hay una pareja de petirrojos europeos (Erithacus rubecula) símbolo de compasión (Bruce-Mitford, 2000, 71). Es una de las especies más populares y reconocibles por su mancha anaranjada en el pecho, garganta y cara. Según Campbell $(1992,194)$, una antigua leyenda explica su color singular y narra que cuando Jesús estaba muriendo en la cruz, el pájaro se puso a su lado y le cantó al oído para consolarlo en su dolor. La sangre de sus heridas le manchó el busto, y desde entonces presenta la marca de la sangre de Cristo, además aparece el pinzón vulgar (Fringilla coelebs) y todos ellos prefiguran de nuevo la Pasión de Jesucristo ya que:

El jilguero, el petirrojo y el pinzón, movidos por la compasión ante los sufrimientos de Jesús, se pusieron los tres activamente a retirar de su carne una por una las puntas de la corona de espinas. Los tres quedaron heridos por las espinas, todavía mojadas de la sangre divina, y las partes de sus cuerpecillos quedaron gloriosamente marcadas: el jilguero se ganó el casquete rojo que lleva en la cabeza, y el petirrojo y el pinzón su pectoral de color sangre. Y como perpetua herencia de honor, sus descendientes han participado de aquel privilegio (...) (Charbonneau-Lassay, 1997, 533).

Martin Shongauer hizo uso de su estudio de peonías, concretamente la Paeonia officinalis L., a la que Mirella Levi D’Ancona (1977, 301) otorga distintos significados aludiendo a varios autores. Según Bartolomeo Ambrosini, durante el cristianismo, se convirtió en símbolo de salvación. La raíz griega del nombre de peonía es la misma que la palabra usada para niño, convirtiéndose así en la planta de los que fallecían a temprana edad. Es una señal del destino fatídico de Jesús, ya que cuando sea hombre morirá en la cruz y por otro lado resucitará de entre los muertos. De acuerdo con John Goodyer, fue "buena contra los venenos, maldiciones y pesadillas" (Levi D’Ancona, 1977, 30). En la Antigüedad se tenía la convicción que la peonía poseía poderes mágicos, siendo utilizada por los griegos para alejar a los malos espíritus (Bruce-Mitford, 2000, 54). Dado que muchos de los elementos analizados adelantan acontecimientos como la Pasión, la planta se interpreta como amuleto o talismán ante lo que acontecerá al Niño una vez se haya convertido en hombre. En la actualidad se mantiene la creencia de que las flores rojas o elementos de este color, repelen los malos pensamientos y mal de ojo, tradición que viene de antaño (Becker, 2003, 360) ${ }^{14}$. Mar Rey $(2008,86)$ le otorga a la peonía el nombre de hierba de San Jorge, denominada así por florecer en fechas próximas a la festividad de este mártir cristiano. Se hace representar junto a un caballo blanco y un dragón, este último entendido como la personificación del Mal, por lo que hace referencia a la función protec-

${ }^{14}$ El coral rojo fue utilizado como amuleto y talismán. Su presencia fue frecuente en obras de temática religiosa como en la Virgen con niño y con ángeles de Giovanni di Marco (Florencia, 1385-1437), 1410. Blanton Museum of Art, Texas. Aparece representado además en muchos retratos pictóricos de infantes españoles del siglo XVI. La raíz de peonía adquirió también efecto apotropaico (Franco, 2008; Horcajo, 1999). 


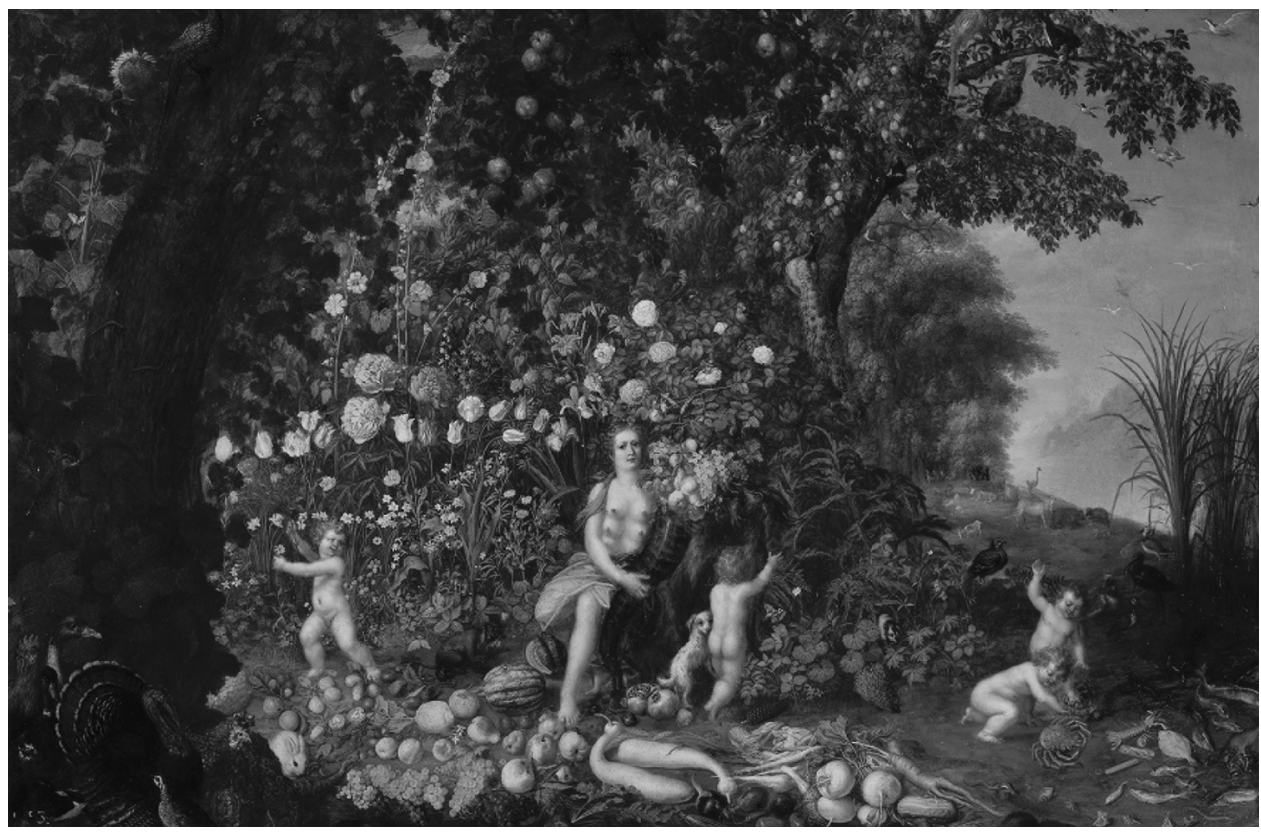

Fig. 7. Brueghel el Joven, Jan, La Abundancia, c. 1625, Museo del Prado, Madrid (España).

tora de la planta. Se relaciona también con la castidad de la Virgen - pues de acuerdo con Joannes Ammonius Agricola, fue símbolo de castidad "paeonia a latinis casta herba (...) dicitur"- vinculándose por tanto, con la rosa blanca, el lirio y el huerto cerrado mencionados anteriormente y aludiendo todo ello a la Encarnación.

\section{LA PEONÍA EN TEMAS ALEGÓRICOS: La Abundancia de Jan Brueghel, el Joven}

La Abundancia, realizada hacia 1625 por Jan Brueghel, el Joven (1601-1678) -pintor flamenco de naturalezas muertas, paisajes, escenas mitológicas y alegóricas- está repleta de elementos que el artista no ha situado al azar (Fig. 7). El eje central lo marca una joven con el torso desnudo mostrando sus seis pechos. Con su brazo izquierdo sostiene una cornucopia de la que sobresalen frutos [melocotón (Pronus), uva (Vitis vinifera L.), higo (Ficus carica) o cereza (Prunus avium)]. La escena se completa con cuatro niños jugando entre un sinfín de recursos naturales pintados con gran realismo. Brueghel inunda la superficie pictórica con diversos animales entre los que se encuentran: mamíferos domésticos [perro (Canis lupus familiaris), gallina (Gallus gallus domesticus), conejo (Oryctolagus cuniculus), pavo de corral (Meleagris gallopavo)]; salvajes [mono (Primates)]; ejemplares exóticos [pavo real (Pavo cristatus) y guacamaya roja (Ara chloroptea)]; reptiles [tortuga (Testudines)], insectos, peces y crustáceos [centollo (Maia squinado)]. El artista además, realiza todo un alarde decorativo a través de: flores [anémona (Anémona spp.), clavel chino 
(Dianthus chinensis), peonía (Paeonia), espuela de caballero (Consolida ajacis), Jacinto (Narcissus jonquilla), malva real (Athaea rosea) o la rosa antigua (Rosa centifolia)]; verduras [pimiento (Capsicum annuum), puerro (Allium ampeloprasum var. porrum), berenjena (Solanum melongena)]; frutas [melocotón, cereza, granada (Punica granatum)] y árboles. Sorprende en la composición que especímenes tan dispares aparezcan juntos. Se puede pensar que Jan Brueghel personifica a través de la joven la alegoría de la Abundancia, tema célebre en la pintura de gabinete durante los siglos XVI-XVII (Mena, 2014, 132). Es habitual representarla bajo la forma de una ninfa coronada de flores, sosteniendo con una mano una cornucopia, denominada cuerno de la abundancia o de Amaltea ${ }^{15}$ lleno de frutos (Revilla, 2012, 16). Suele portar un haz de espigas, pues su prototipo clásico es Ceres ${ }^{16}$, diosa de la fertilidad de la tierra (Carmona, 2002, 28-29). Brueghel en la pintura sitúa ramas de trigo a los pies de la joven y la hace acompañar de niños como a la Caridad ${ }^{17}$. Según James Hall $(1987,26)$ el término abundancia "se asocia a grandes provisiones de alimentos, base del bienestar humano, que fluyen de la paz, la justicia y el buen gobierno".

La joven posee numerosas mamas como la diosa de la fertilidad Diana de Éfeso ${ }^{18}$, cuyo origen eran dátiles símbolo de fecundidad (Fig. 8). Presenta en el cuello una guirnalda y muestra tres hileras de mamas superpuestas. Tanto su cuerpo como su falda se cubren por figuras y prótomos de animales, entre los que se distinguen ciervos, leones y seres híbridos (Elvira, 2008, 596). En la pintura renacentista, una joven con similares características y rodeada de flores, hortalizas y otros testimonios de la fecundidad de la tierra evocaba la Madre Naturaleza - pues el pecho fue visto como fuente de vida y alimento- siendo para Cesare Ripa, Diana de Éfeso símbolo de ésta (Tervarent, 2002, 380).

En la obra de Joannes Sambucus $(1564,74-75)$, aparece una joven con varios pechos en el emblema que se corresponde a la Diferencia entre la Física y la Metafísica, relacionada esta última con la rama de la filosofía que estudia la naturaleza (Fig. 9). Lo que se muestra por tanto, es la imagen de la abundancia de la tierra nutricia o de las producciones de la naturaleza, según la concepción de Macrobio (Tervarent, 2002, 381). El escultor italiano Niccolò Tríbolo (1500-1550) representó un siglo antes que Brueghel, a la Diosa Na-

15 Amaltea es el nombre de la nodriza que amamantó a Júpiter, pudiendo ser para los antiguos tanto la cabra que dio su leche al niño como una ninfa (Grimal, 1981, 24). Según Luis Pastor (1866, 14-16), este dios en agradecimiento dispuso a la cabra en el cielo, dando uno de sus cuernos a las ninfas que lo habían cuidado en su niñez, el cual estaba dotado de la virtud de producir cuanto éstas desearan. La cornucopia puede ser el atributo de Ceres, de la Abundancia y de la Tierra (Hall, 1987, 91).

16 La Démeter griega es la diosa de la agricultura, especialmente asociada a los cereales. Algunas veces fue adorada como madre-tierra, fuente primera de la fertilidad. Como personificación de la abundancia en la tierra lleva una corona de espigas o una cornucopia llena de frutas y hortalizas (Pastor, 1866, 82). Ceres fue una antiquísima potencia de la vegetación, y se relaciona con una raíz que significa brotar (Hall, 1987, 99).

17 A la Caridad también se le puede representar portando una cornucopia o un recipiente con frutas (Hall, 1987, 74).

18 En Lacio existía una diosa denominada Diana cuyos cometidos coincidían con la diosa griega Ártemis; era la señora de la vida salvaje, pero también tenía parte en el día, en los alumbramientos de animales y seres humanos. Es probable que la iconografía griega empezase a imponerse desde el siglo VI a.C. y que Diana adquiriera finalmente la representación de Ártemis (Elvira, 2008, 188). La Ártemis de Éfeso es una personificación divina de la fecundidad y una de las formas que adopta la gran diosa-madre de Oriente. Presenta el cuerpo enfundado en una estrecha vestidura, llena de cabezas de animales, que deja descubierto, a la altura del pecho gran número de senos (Guirand, 1962, 162). 


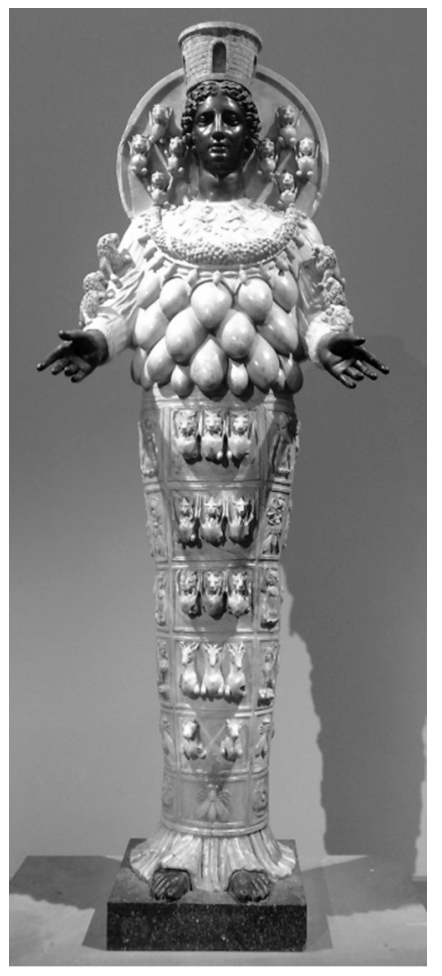

Fig. 8. Artemis Farnesia. Copia del siglo II d.C. de la Artemis de Éfeso, Museo Arqueológico Nacional de Nápoles (Italia).

Fig. 9. Diferencia entre Física y Metafísica (Sambucus, 1564, 74).

\section{Phyficx ac Metaphyficx differentia.}

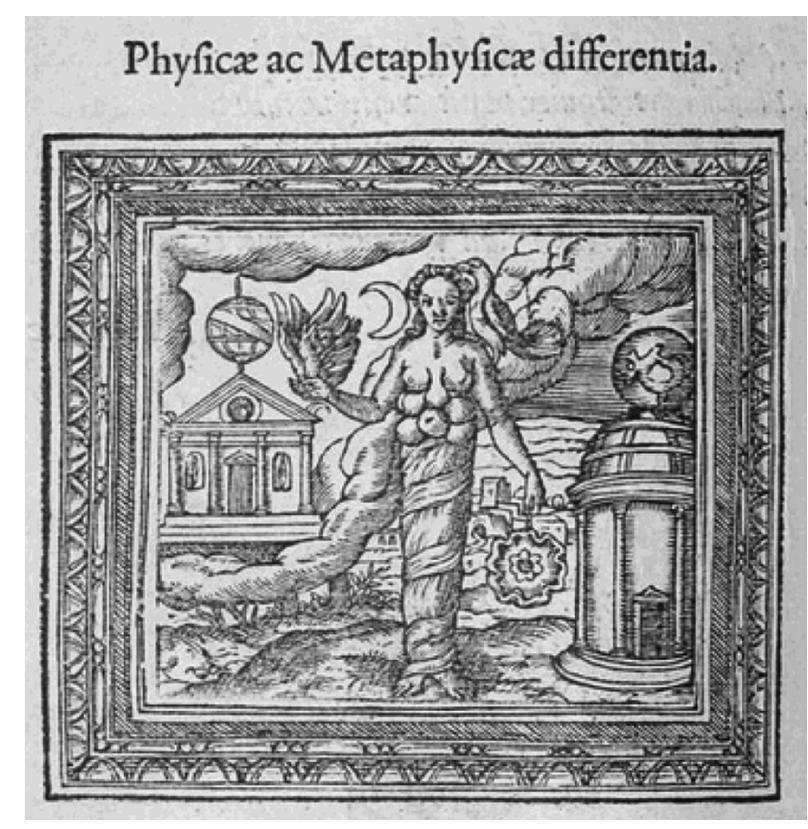


turaleza del mismo modo. Una muchacha rodeada de mamas desde el busto hasta los tobi1los, niños, frutos y animales (Fig. 10). Como apunta María del Carmen Alberú (1995, 40): "Hubert François Gravelot y Charles Nicolas Cochin escribieron que en la Antigüedad se representaba a la naturaleza cubierta de senos y rodeada de los diferentes seres que ella procrea". En la ilustración de la Nature de estos autores, se dispone una mujer desnuda y a su lado la escultura de Diana de Éfeso (Gravelot y Cochin, 1773, 74). Una figura similar se muestra en la imagen de la Medecine, entendida como ciencia dedicada al estudio de la vida (Gravelot y Cochin, 1773, 54). Este modo de representar la Naturaleza se difundió en estampas. Ejemplo de ello es La Diana de Éfeso una Alegoría de la Naturaleza de Joseph Werner (1637-1710). La diosa porta sus pechos al aire y se rodea de animales salvajes (león), domésticos (vaca), terrestres (tortuga), marinos (caracola), además de frutos y flores como en la pintura analizada (Fig. 11).

En la composición de Brueguel se entremezclan especies vegetales que florecen a lo largo del año: de primavera peonías, un girasol (Helianthus annuus), fresas (Fragaria), cerezas y rosas (Rosa centifolia) de finales de este periodo; malva real (Athaea rosea), espuela de caballero (Consolida ajacis), freesias, melón (Cucumis melo), higo, melocotón, sandía, pimiento, de verano; uvas, membrillo (Cydonia oblonga), hiedra (Hedera) de otoño; y anémona, jacinto (Narcissius jonquilla), calabaza y berenjena (Solanum melongena) de invierno. Al considerar a la joven como imagen de la Madre Naturaleza y los niños representación de las cuatro estaciones del año, pintar peonías en esta obra no es banal pues el artista alude con ello a una de las flores propias del periodo primaveral.

\section{LAS PEONÍAS EN ASIA}

La peonía también tuvo gran consideración más allá del territorio europeo. A continuación mostraremos la importancia de esta flor en la cultura asiática, pues no sólo destacó en el ámbito de la medicina -como se ha visto anteriormente en el Manual ilustrado de plantas medicinales- sino que ocupó un lugar preponderante en las artes visuales.

\section{La pintura China}

La siguiente obra titulada Peonies pertenece al artista chino Yun Shouping, uno de los pintores mejor valorados de los seis grandes maestros de la dinastía Qing (1644-1912). Forma parte del Álbum de flores y paisajes y está realizada al estilo de tinta y aguadas "sin hueso"19 (Fig. 12). Se observa tres flores de Paeonia suffruticosa: una roja a la izquierda que se extiende hacia delante, en el centro una morada escondida entre sus hojas y a la derecha una blanca colocada en segundo plano respecto a la roja. Esta especie es autóctona de las zonas montañosas de Qinling y Dabashan en el oeste de China ${ }^{20}$. La peonía (mudán) posee grandes flores de colores brillantes y es conocida como "el rey floral", "la

\footnotetext{
19 Manchas de color libre sin contorno (Honour y Fleming, 1987, 516).

20 Texto extraído de: Li Quiushi, 2014.
} 


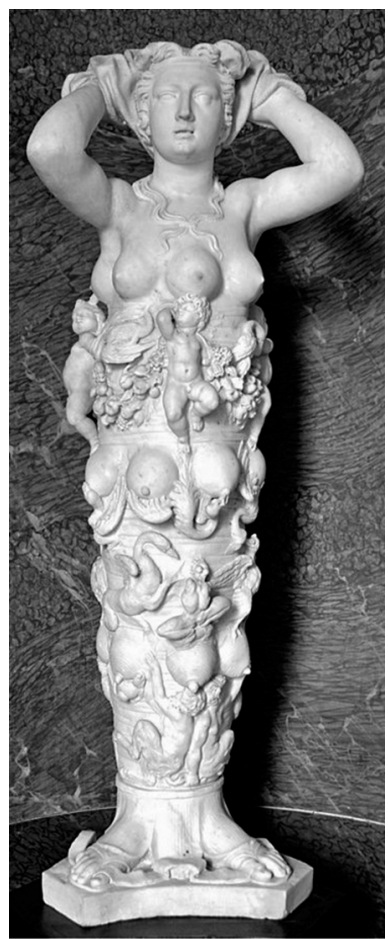

Fig. 10. Niccòlo Tríbolo (15001550), La Naturaleza, c. 1529. National du Château, Fontainebleu (Francia).

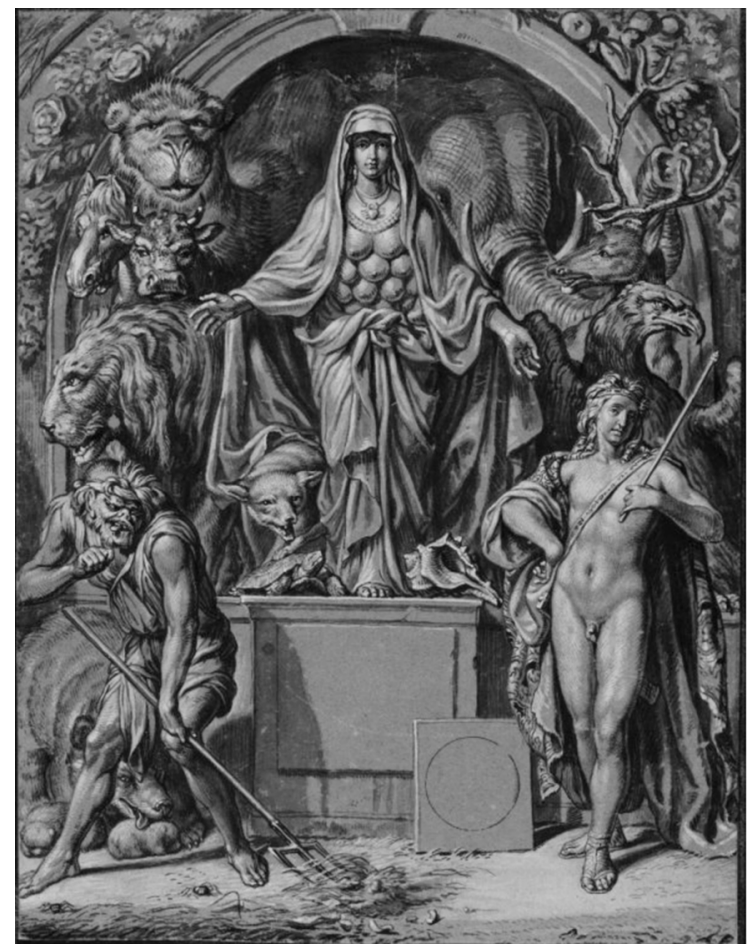

Fig. 11. Joseph Werner (1637-1710), La Diana de Éfeso una Alegoría de la Naturaleza, c. 1680, Art Institute Chicago.

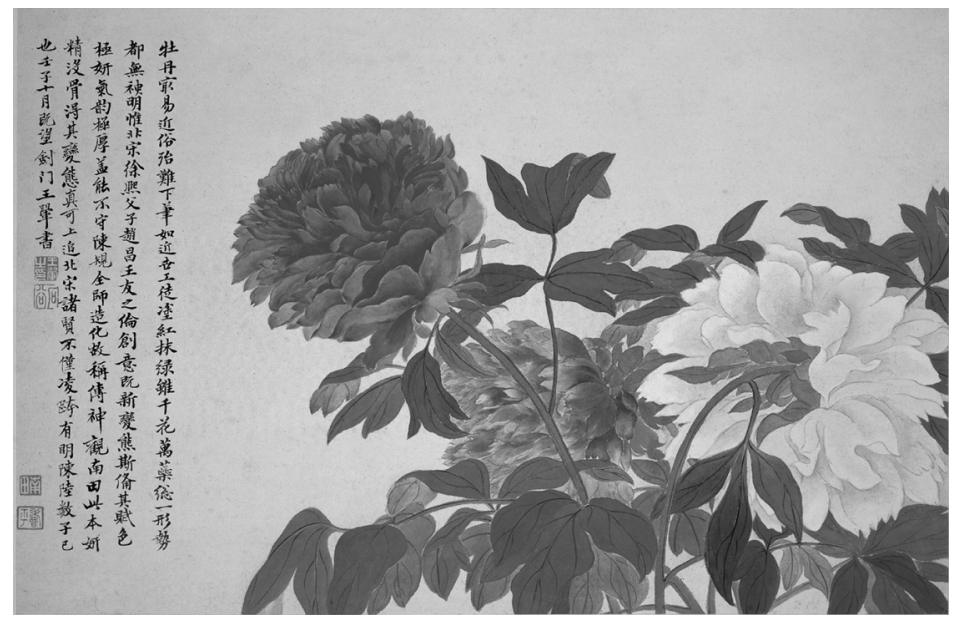

Fig. 12. Yun Shouping, Peonies, National Palace Museum, Taipei (China). 
flor de la fortuna" o "la flor de la beldad nacional", convirtiéndose en símbolo de felicidad, prosperidad, suerte y fortuna. En China, también es significativa la peonía híbrida (Paeonia lactiflora) denominada sháoyào, nombre por el que se conoció la especie suffruticosa hasta la dinastía Tang (618-907). El inicio del cultivo del mudán como planta ornamental se remonta al periodo de las dinastías Meridionales y Septentrionales (220-589). Sin embargo, el primer jardín real dedicado a este vegetal fue creado hacia el año 600 cuando el emperador Sui-yang ordenó el cultivo de flores exóticas en el jardín Xi Yuan en Luoyang. La peonía pasó a ser entonces la favorita de la emperatriz Wu Zetian (625-705).

Durante el reinado de Xuanzong (685-762) se desarrollaron nuevas especies mediante la técnica del injerto. A este periodo corresponde un verso de Li Zhengfeng donde dice que después de beber se extasió "contemplando la belleza de las flores. Su aroma rico se ha quedado en mi ropa sin desvanecerse”. De este modo se conoce al mudán por la expresión "color nacional y fragancia celestial", convirtiéndose en la flor más apreciada en China (Lou Qingxi, 2002, 12). El cultivo se extendió a Pekín, Heze, Lanzhou y regiones ubicadas alrededor del Lago Tai. Se propagó fuera de China durante la dinastía Tang y se introdujo en Japón alrededor del siglo VIII gracias a la Ruta de la Seda y a los avances en el ámbito de la navegación marítima. Con las expediciones efectuadas por Inglaterra, Estados Unidos, Francia y Holanda, la peonía traspasó el continente asiático.

El mudán es símbolo de riqueza y honor en China (Chevalier, 1991, 811), elemento que encontramos en diversas manifestaciones artísticas (papel, orfebrería, laca, textil). Es venerado en Oriente desde hace miles de años como portador de fortuna y de matrimonio feliz (Dafne \& Cloe, 2014, 132). Pintado de modo vibrante, es agüero de buena fortuna, situándose en los hogares para atraer buenos presagios. Sus flores blancas simbolizan las muchachas jóvenes distinguidas por su ingenio y belleza, mientras que las rojas, aluden a la vitalidad siendo admiradas y valoradas. Una visión más erótica se asocia a los genitales femeninos: cuando el rocío - que representa al semen- cae, la flor de peonía se abre. También simbolizó la apertura de la sociedad durante la dinastía Tang, incluso en términos sexuales, pues fue el periodo de mayor libertad en ese aspecto (Wang, 2012, 293).

\section{La peonía en el tatuaje japonés: horimono $^{21}$}

En Japón la peonía es valiosa, destacando la representación de su flor en la disciplina artística del tatuaje tradicional denominado horimono (Fig. 13). La costumbre de tatuar el cuerpo es constante en algunas culturas y, en el caso del país nipón, representa una de las prácticas más arraigadas y con mayor protagonismo por su fuerte carga simbólica. Pese a que llevar el cuerpo tatuado no esté actualmente bien visto, esta manifestación se legitima como guardiana de la iconografía tradicional y de las creencias más antiguas: galería de deidades del pensamiento shintoísta, representación de la flora (loto, crisantemos, flor del cerezo, peonía y hoja de arce rojo), del bestiario japonés (dragón, carpa y tigre), leyendas épicas de héroes y guerreros nacionales, imágenes del panteón budista o mode-

21 Como explica Juan Pedro Cantero, el horimono proviene del verbo horu, que significa: grabar, esculpir, cincelar, tallar o labrar. Por extensión, el término, designa a la práctica o a los elementos realizados por dichos procedimientos en el que predomina el ideal de belleza (Cantero, 2008, 31-48). Para ampliar este apartado ver: Miller, 1997; Sanders, 1998. 


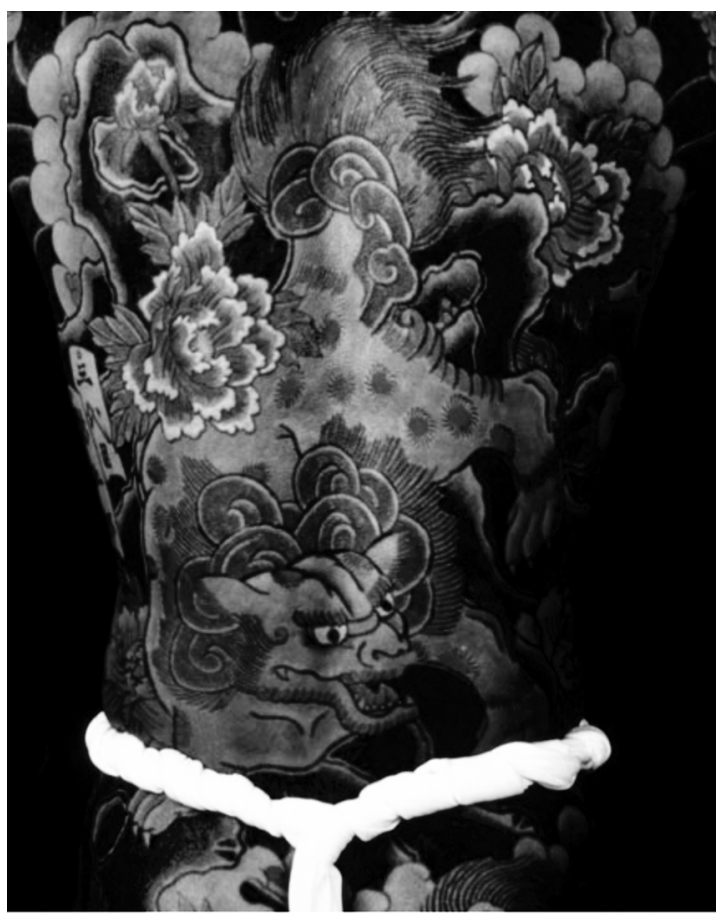

Fig. 13. Sandi Fellman, Tattoos.

los de la mitología y la literatura china. El horimono cubre toda la superficie del cuerpo -desde el cuello a tobillos- exceptuando las palmas de manos y pies por poseer muchas terminaciones nerviosas. Es habitual que los motivos tatuados se refieran al carácter, personalidad y cualidades poseídas o anheladas (coraje, honestidad, lealtad, nobleza o compromiso).

La peonía (botan) más representada posee de cinco a diez pétalos, dependiendo su significado del color con que se ejecute. La blanca es signo de juventud, espíritu cultivado y belleza, actuando como talismán para atraer la buena suerte o salud. Es la flor de la riqueza, distinción, y símbolo tradicional de las jóvenes que sobresalen por su belleza. Alude a la complementariedad de opuestos, ya que la peonía tiene influencia positiva en la mujer sobre su hombre por cuanto se refiere a vivir juntos en armonía (Dafne \& Cloe, 2014, 132-133). La roja en contraposición tiene connotaciones funestas y violentas. Representa la masculinidad, coraje y valor asociado a la figura del samurai, cuya sangre derramada en la batalla es roja como esta flor. Ésta aparecía en su jinbaori-guardapolvo que cubría su armadura- junto con animales protectores y la heráldica del clan (Fig. 14). Sin embargo, en la actualidad, son muchas jóvenes tanto asiáticas como occidentales, las que eligen la peonía de color rojo para tatuársela en su cuerpo. 
Fig. 14. Jinbaori japonés (ss. XVIII-XIX), Museo Metropolitano de Arte, Nueva York.

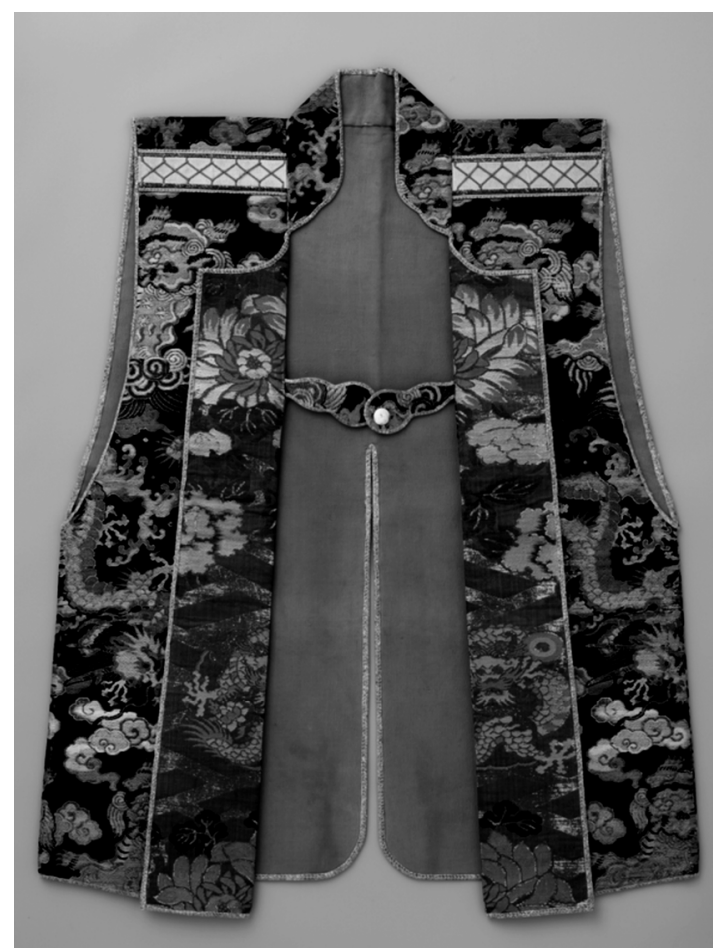

\section{CONCLUSIÓN}

Este trabajo debe ser tomado como una aproximación al estudio de la representación de la peonía en distintos soportes, donde hemos pretendido demostrar que no es exclusivamente una flor, usada como elemento ornamental y admirada por su deslumbrante belleza. A pesar de que saturar con vegetación muchas obras pueda tener una dimensión visual y estética, puede esconder por otro lado, algún simbolismo deliberado haciendo complicada su lectura y pasando inadvertido -en la mayoría de casos- su mensaje por el público que la contempla.

La peonía fue valorada desde la Antigüedad tanto por sus propiedades medicinales y terapéuticas como por esconder un significado oculto, además no sólo está presente en la pintura religiosa y mitológica europea, sino que es importante en otras culturas como la asiática.

Martin Shongauer construye a través de La Virgen del jardín de las rosas un mensaje para los fieles. Cada componente de la tabla hace referencia a un elemento vinculado con la pureza de la Virgen, y donde la omnipresencia del color rojo evoca el drama de la Pasión de Cristo. La peonía en esta obra refuerza el mensaje del artista, pues se considera esta flor símbolo de castidad además de salvación, actuando como protección ante el futuro sufrimiento de Jesús.

En la obra de Jan Brueghel, consideramos que la joven no hace referencia a la alegoría de la Abundancia, más bien representa la Madre Naturaleza pues se acompaña de todos 
los seres que ella procrea -ya sean animales o vegetales- además de las cuatro estaciones. El artista al pintar flores de peonía remarca con ello la temporada de primavera, pues es en este periodo cuando florecen.

La peonía también ocupa un lugar destacado en el arte y en la literatura del continente asiático. En China, las flores son un tema recurrente dentro de la historia del arte. Antiguamente los pintores les concedían ciertas connotaciones culturales como reflejo del pensamiento tradicional de la "armonía entre el hombre y la naturaleza". El mudán convertido desde antaño en símbolo de fortuna y riqueza, se sigue utilizando en la decoración de la mayoría de hogares como símbolo de buen agüero. En Japón por otro lado, la peonía forma parte de su iconografía tradicional, y pervive tatuada en la piel gracias a la técnica ancestral del horimono, donde dependiendo del color de la tinta utilizada adquiere distintas connotaciones.

\section{BIBLIOGRAFÍA}

ALBEROLA, G. (1892): Mitología vegetal: leyendas de plantas, Madrid, Tipografía de Manuel Ginés Hernández, 1892, 239 p.

ALBERÚ, M. C. (et al.) (1995): La ciencia de las imágenes, México, Universidad Iberoamericana, $49 \mathrm{p}$.

AÑóN, C. (dir.) (1996): El lenguaje oculto del jardín: jardín y metáfora, España, Editorial Complutense, $274 \mathrm{p}$.

BAIRD, M. (2001): Symbols of Japan. Thematic motifs in Art and Design, New York, Rizzoli Publications, $336 \mathrm{p}$.

BALDERAS, G. (2008): Cristianismo, sociedad y Cultura en la Edad Media: una visión contextual, México D. F., Universidad Iberoamericana, 542 p.

BECK, B. (2000): "Jardin monastique, jardin mystique. Ordonnance et signification des jardins monastiques médiévaux", Revue d'histoire de la pharmacie, 88, n 327, 377-394.

BECKER, U. (2003): Enciclopedia de los símbolos, Barcelona, Robinbook, 350 p.

BESLER, B. (1613): Hortus Eystettensis sive diligens et accurata omnium plantarum, florum, stirpium ex variis orbis terrae partibus singulari studio collectarum, quae in celeberrimis viridiariis arcem episcopalem ibidem cingentibus hoc tempore conspiciuntur, delineatio et ad vivum repraesentatio opera Basilii Besleri philiatri et pharmacopoei, vol. I, Núremberg (Alemania), [s.n.], $366 \mathrm{p}$.

BIALOSTOCKI, J. (1998): El arte del siglo XV: de Parler a Durero, Madrid, Istmo, 520 p.

BIANCHINI, F.; CARRARA, A. (1997): Guía de Plantas y Flores, Madrid, Grijalbo, 550 p.

BRUCE-MITFORD, M. (2000): El libro ilustrado de signos y símbolos, $2^{\circ}$ ed., Toledo, Blume, 128 p.

BUCHAND, W. (1792): Farmacopea y tabla general de las materias contenidas en la medicina doméstica, Madrid, Imprenta Real, 419 p.

BYNUM, C. W. (1988): Holy Feast and Holy Fast: The Religious Significance of Food to Medieval Women, $2^{\circ}$ ed., Berkley, University of California Press, 464 p.

CABELLO, S. A. (2010): "En torno al vino y los phármaka en la Odisea: una visión multidisciplinar", Thamyris, nova series: Revista de Didáctica de Cultura Clásica, Griego y Latín, nº 1, 61-84.

CAMERARIUS, J. (1668): Joachimi Camerarii Symbolorum et emblematum, centuriae quatuor quarum prima Stirpium secunda Animalium quadrupedium tertia Volatilium et Insectium quarta Auatilium et Reptilium, Rariores propietates Historias ac sententias memorabiles non paucas breviter exposit, Maguntice, Botgeat, $834 \mathrm{p}$.

CAMPBELL, J. (1992): Symbolic and Mythological Animals, Londres, Aquarian Press, 284 p.

CANTERO, J. P. (2008): "Horimono: el tatuaje tradicional japonés", en: San Ginés Aguilar, P. (coord.), Nuevas perspectivas de investigación sobre Asia Pacífico, Granada, Universidad de Granada, 31-48. 
CARMONA, J. (2002): Iconografía cristiana: Guía básica para estudiantes, Madrid, Istmo, 192 p. CERVERA, I. (1986): El Arte chino, Madrid, Historia 16, 162 p.

CHARBONNEAU-LASSAY, L. (1997): El bestiario de Cristo: el simbolismo animal en la antigüedad y la Edad Media, vol. II, Palma de Mallorca, Sophia Perennis, 515 p.

CHEVALIER, J. (dir.) (1991): Diccionario de los símbolos, Barcelona, Herder, 1108 p.

CIRLOT, J. E. (1997): Diccionario de símbolos, Madrid, Siruela, 473 p.

COLMEIRO, M. (1871): Diccionario de los diversos nombres vulgares de muchas plantas usuales ó notables del Antiguo y Nuevo Mundo, con la correspondencia científica y la indicación abreviada de los usos é igualmente de la familia á que pertenece cada planta, Madrid, Imprenta de Gabriel Alhambra, $252 \mathrm{p}$.

CULLEN, W. (1795): Tratado de materia médica, Madrid, Imprenta de Don Benito Cano, 404 p.

DAFNE \& CLOE (2014): Linguaggio e significato dei fiori, Versión Kindle, R.E.I., 136 p.

DAVIS, D. (2014): El jilguero y Fabritius: La verdadera historia de un cuadro y un pintor, Versión Kindle, Lumen, $160 \mathrm{p}$.

DEL OLMO, A.-M. (2008): "El trazo oculto", Asociación cultural Seshat. Recurso en línea: http://www.asociacionseshat.com/articulos/trazo-oculto.htm (19/03/2016).

DIÓSCORIDES, P. (c. 500-699): De materia medica, Biblioteca Digital Mundial, 170 p.

EBERHARD, W. (1998): A dictionary of Chinese symbols: hidden symbols in Chinese life and thought, New York, Routledge \& Kegan Paul, 336 p.

ESCOBAR, J. M.; DÍAZ, A. M. (1993): "Hortus conclusus. El jardín cerrado en la cultura europea", Cuadernos de Investigación urbanística, $\mathrm{n}^{\circ} 32,1993,48 \mathrm{p}$.

ELVIRA, M. Á. (2008): Arte y mito: Manual de iconografía clásica, Madrid, Sílex, 651 p.

FERRACES, A. (2009): "Magia y terapia: edición, traducción y comentario de un fragmento tardoantiguo sobre la peonía", en: Ferraces, A. (ed.), Fito-zooterapia antigua y altomedieval, A Coruña, Universidade da Coruña, 147-170.

FISHER, C. (2006): Las flores en los Manuscritos Medievales, Madrid, Turner, 212 p.

FONT, P. (1973): Plantas medicinales: el Dioscórides renovado, Barcelona, Labor, 1184 p.

FRANCO, A. (2008): "Algunas fuentes medievales del Arte Renacentista y Barroco", Anales de la Historia del Arte, volumen extraordinario, 73-87.

FUCHS, L. (2005): Historia de las yervas y plantas, Salamanca, Ediciones Universidad de Salamanca, $375 \mathrm{p}$.

GÓMEZ-MORENO, Á. (2011): "Borduras y flores en los libros de horas de la fundación Lázaro Galdiano", en: Yeves, J. A. (dir.), Tiempo de Navidad. Los Libros de Horas de la Fundación Lázaro Galdiano, Madrid, Fundación Lázaro Galdiano, 161-175.

GONZÁLEZ, R. M. (coord.) (1980): Gran enciclopedia Sarpe Plantas y Flores, vol. IV, Madrid, Sarpe, $400 \mathrm{p}$.

GONZÁLEZ SERRANO, P. (2009): Mitología e iconografía en la pintura del Museo del Prado, Madrid, Evohé Didaska, 383 p.

GRAVELOT, H. F., COCHIN, CH. N. (1699-1773): Iconologie par figures; ou, Traité complet des allégories, emblêmes, etc. Ouvrage utile aux artistes, aux amateurs, et peuvent servir à l'éducation des jeunes, vol. III, París, Lattré graveur, $222 \mathrm{p}$.

GREENAWAY, K. (1884): The Language of flowers, London, George Routlege and sons, 92 p.

GRIMAL, P. (1981): Diccionario de mitología griega y romana, Barcelona, Paidós, 672 p.

GUIRAND, F. (dir.) (1962): Mitología general, Madrid, Editorial Labor, 678 p.

HALL, J. (1987): Diccionario de temas y símbolos artísticos, Madrid, Alianza, 328 p.

HARTLIEB, J.: (c.1492), Kräuterbuch, Biblioteca Digital Mundial, 183 p.

HOMERO (1993): Odisea. Edición de José Manuel Pabón, Madrid, Gredos, 409 p.

HOMERO (1996): Ilíada. Edición de Emilio Crespo, Madrid, Gredos, 651 p.

HONOUR, H.; FLEMING, J. (1987): Historia del Arte, Barcelona, Reverté, 448 p. 
HORCAJO, N. (1999): “Amuletos y talismanes en el retrato del príncipe Felipe Próspero de Velázquez”, Archivo Español de Arte, 72 (288), 521-530.

ILDREWE, M. (1874): The Language of Flowers, Boston, Lee and Shepard, 216 p.

IWASAKI, KAN'EN (1830-1844): Manual ilustrado de plantas medicinales, Japón, Biblioteca Digital Mundial, $207 \mathrm{p}$.

LAGUNA, A. (1555): Pedacio Dioscórides Anazarbeo acerca de la materia medicinal y los venenos mortíferos, Anvers, en casa de Juan Latio, $616 \mathrm{p}$.

LEÓN, L. (1994): Cantar de Cantares de Salomón, Madrid, Gredos, 316 p.

LEVI D'ANCONA, M. (1977): The Garden of the Renaissance. Botanical Symbolism in Italian Painting, Firenze, Leo S. Olschki, 608 p.

LI QUIUSHI (2014): "El mudán (peonía): símbolo de riqueza y prosperidad”, Revista Instituto Confucio, $\mathrm{n}^{\circ}$ 25, vol. 4, 50-55.

LÓPEZ PIÑERO, J. M. (dir.) (1996): Las plantas del mundo en la historia: Ilustraciones botánicas de cinco siglos, Valencia, Fundación Bancaja, 217 p.

LÓPEZ TERRADA, Mª J. (1996): "El mundo vegetal en la pintura española del Renacimiento al siglo XIX”, en: López Piñero, J. M. (dir.), Las plantas del mundo en la historia. Ilustraciones botánicas de cinco siglos, Valencia, Fundación Bancaja, 86-95.

LÓPEZ TERRADA, M ${ }^{\mathrm{a}}$ J. (2005-2006): "El mundo vegetal en la mitología clásica y su representación artística", Ars Longa. Cuadernos de Arte, $\mathrm{n}^{\circ}$ 14-15, 27-44.

LÓPEZ TERRADA, M ${ }^{\mathrm{a}}$ J. (2009): “Arte y ciencia: el caso de la pintura valenciana de flores”, en: Hermosilla, J. (coord.), La ciudad de Valencia: historia, geografía y arte de la ciudad de Valencia, vol. II, Valencia, Publicacions de la Universitat de València, vol. 2, 454-460.

LOU QINGXI (2002): La arquitectura tradicional en China, Beijing, China Intercontinental Press, $176 \mathrm{p}$.

MANUAL DE PIADOSAS MEDITACIONES, Barcelona, Imprenta de Sierra y Martí, 1833, 518 p.

MENA, M. (com.) (2014): La Belleza Cautiva: Pequeños tesoros del Museo del Prado, Madrid, Obra Social la Caixa, 220 p.

MENDOZA, C. (1993): La leyenda de las plantas mitos, tradiciones, creencias y teorías relativos a los vegetales, Barcelona, Alta Fulla, $410 \mathrm{p}$.

MILLER, J.-Ch. (1997): The Body Art Book: A Complete Illustrated Guide to Tattoos, Piercings and Other Body Modifications, New York, Berkley Book, 192 p.

MONREAL, L. (2000): Iconografía del Cristianismo, Barcelona, El Acantilado, 558 p.

OSBORNE, H. (dir.) (2007): Manual de exposiciones de flores, St. Louis (Missouri), National Garden Club, $309 \mathrm{p}$.

OVIDIO, P. (2002): Metamorfosis [traducción Ana Pérez Vega], Alicante, Biblioteca Virtual Miguel de Cervantes, $270 \mathrm{p}$.

PASTOR, L. G. (1866): Iconología o tratado de alegorías y emblemas, México, Imprenta Económica, $180 \mathrm{p}$.

QUER, J. (1784): Flora Española ó Historia de las plantas que se crían en España, Madrid, Joaquín Ibarra, 303 p.

RÉAU, R. (2000): Iconografía del arte cristiano. Introducción general, Barcelona, Serbal, 592 p.

REQUENA, J. L. (2014): “Algunas consideraciones iconográficas sobre la prefiguración de la Pasión de Cristo en su Santa Infancia en la pintura barroca andaluza", en: Gila, L. (coord.), Aquenda et allende: Obras singulares de la Navidad en la Granada moderna (siglos XV-XVIII), Granada, Diputación de Granada, 63-85.

REY, M. (2008): Historia de las hierbas mágicas y medicinales: Plantas alucinógenas, hongos psicoactivos visionarias, hierbas fúnebres... todos los secretos sobre las propiedades y virtudes ocultas del ancestral mundo vegetal, Madrid, Nowtilus, 302 p.

REVILLA, F. (2012): Diccionario de iconografía y simbología, Madrid, Cátedra, 404 p.

SECHI, G. (2007): Diccionario Akal de Mitología Universal, Madrid, Akal, 616 p. 
SEGURA, S.; TORRES, J. (2009): Historia de las plantas en el mundo antiguo, Madrid, Consejo Superior de Investigaciones Científicas, $480 \mathrm{p}$.

SAMBUCUS, J. (1564): Emblemata, Cvm Aliqvot Nvmmis Antiqvi Operis, Anturpiae, Ex Officina Christophori Plantini, $257 \mathrm{p}$.

SANDERS, C. (1998): Customizing the Body: The Art and Culture of Tattooing, Philadelphia, Temple University Press, 288 p.

TALEGÓN, J. G. (1871): Flora bíblico poética o Historia de las principales plantas elogiadas en la Sagrada Escritura y por los poetas antiguos, Madrid, Imprenta Aguado, 520 p.

TEOFRASTO (1988): Historia de las plantas [introducción, traducción y notas por José María Díaz-Regañón López], Madrid, Gredos, 532 p.

TERVARENT, G. (2002): Atributos y símbolos en el arte profano: diccionario de un lenguaje perdido, Barcelona, Ediciones Serbal, 549 p.

TURNER, N.; HENDRIX, L. (1997): Obras Maestras del Museo J. Paul Getty: Dibujos, Los Ángeles, J. Paul Getty Museum, 130 p.

TWOMEY, Lesley (2005): "Relectura del color rojo: la alegoría en la Vita Christi de Isabel de Villena”, en: San Martín, L.; Vidal, R. Las Metamorfosis de la alegoría: discurso y sociedad en la Península Ibérica desde la Edad Media hasta la edad contemporánea, Iberoamericana, Madrid, 189-202.

ÚZQUIZA, T. (2012): Símbolos en el arte cristiano: Breve diccionario ilustrado, Burgos, Sembrar, $331 \mathrm{p}$.

WANG XIN (2012): “Cine como espejo social. El análisis de la narrativa de la película La casa de las dagas voladoras de Zhang Yimou", Fonseca, Journal of Comunication, no 4, 281-298.

ZHANG JIAYI; NIE ZHONGZHENG (2000): Pintura china tradicional: historia cantada en poemas sin voz, Beijing, China Intercontinental Press, $171 \mathrm{p}$. 
